Sains Malaysiana 49(1)(2020): 169-178

http://dx.doi.org/10.17576/jsm-2020-4901-21

\title{
Modification of PTFE Flat Sheet Film via Radiation Induced Grafting Polymerization with Acrylic Acid
}

(Modifikasi Filem Kepingan Rata PTFE melalui Kaedah Pempolimeran Cangkuk Sinaran dengan Asid Akrilik)

\author{
Faezeah Abd Ghani, Khaidzir Hamzah*, Nor Hasimah Mohamed \& Wan NorHaryati Wan Salleh
}

\begin{abstract}
Polytetrafluoroethylene (PTFE) flat sheet film was modified with acrylic acid (AAC) by radiation induced grafting polymerization (RIGP) method using electron beam. The adsorbed doses were varied from 10 to $50 \mathrm{kGy}$, time of grafting from 1 to $3 \mathrm{~h}$ and monomer concentration and temperature were kept constant at $30 \mathrm{wt} . \%$ and $40^{\circ} \mathrm{C}$. The degree of grafting $\left(D_{g}\right)$ and equilibrium degree of swelling (EDS) of the grafted films were then determined. The films were further characterized by Fourier transform infrared spectroscopy (FTIR), scanning electron microscope (SEM), atomic force microscope (AFM), X-ray diffraction (XRD), and optical water contact angle. $D_{\text {g }}$ within the range of $17 \%$ to $210 \%$ were obtained for doses from 10 to $50 \mathrm{kGy}$ within time of grafting from 1 to $3 \mathrm{~h}$. The grafted film (PTFE-g-AAC) showed increased hydrophilicity leading to an increase in EDS. The successful grafting process was confirmed by FTIR results that showed characteristics peaks for carbonyl and hydroxyl group and a decrease in crystallinity for the PTFE-gAACfilm. SEM images showed that PTFE-g-AAC films had less fibrillar compared to PTFE film and was consistent with the decrease in roughness for the PTFE-g-AAC film. This study indicated that modifying PTFE film by grafting AAC could significantly improve the hydrophilicity of PTFE film. The PTFE-g-AAC films has potential as a heavy metal adsorbent as it can remove at least $75 \%$ of $\mathrm{Fe}$ ion and $50 \%$ of $\mathrm{Pb}$ ion from competitive media.
\end{abstract}

Keywords: Acrylic acid; adsorbent; polytetrafluoroethylene; radiation grafting

\section{ABSTRAK}

Filem kepingan rata politetrafluoroetilena (PTFE) telah diubah suai dengan asid akrilik (AAC) melalui kaedah pempolimeran cangkuk sinaran (RIGP) menggunakan alur elektron. Dos terserap diubah daripada 10 sehingga $50 \mathrm{kGy}$, masa cangkukan dari 1 sehingga 3 jam manakala kepekatan monomer $30 \%$ pada suhu $40^{\circ} \mathrm{C}$. Darjah pencangkukan (D) dan darjah keseimbangan pengembangan (EDS) filem ditentukan. Seterusnya filem dianalisis menggunakan spektroskopi transformasi Fourier inframerah (FTIR), mikroskopi pengimbas elektron (SEM), mikroskopi tenaga atom (AFM), pembelauan sinar-X $(X R D)$ dan sudut sentuhan optik. Keputusan diperoleh menunjukkan $D_{g}$ berada pada julat antara $17 \%$ sehingga $210 \%$ untuk dos 10 hingga $50 \mathrm{kGy}$ pada masa cangkukan antara 1 sehingga $3 \mathrm{jam}$. Filem yang dicangkuk (PTFE-g-AAC) menunjukkan peningkatan sifat hidrofilik yang memberi kesan kepada peningkatan EDS. Keberhasilan pencangkukan dapat disahkan melalui FTIR iaitu kewujudan puncak bagi kumpulan berfungsi karbonil dan hidroksil serta penurunan sifat hablur filem PTFE-g-AAC. Imej SEM membuktikan filem PTFE-g-AAC mempunyai kurang fibril berbanding filem PTFE dan konsisten dengan penurunan darjah kekasaran untuk PTFE-g-AAC. Kajian ini menunjukkan dengan mengubahsuai filem PTFE dengan AAC secara pempolimeran cangkukan sinaran dapat meningkatkan sifat hidrofilik filem PTFE. Filem PTFE-g-AAC mempunyai potensi sebagai penjerab logam berat sebagaimana ia dapat menyingkirkan $75 \%$ ion $\mathrm{Fe}$ and $50 \%$ ion $\mathrm{Pb}$ daripada media yang kompetitif.

Kata kunci: Asid akrilik; pengrafan radiasi; penjerab; politetrafluoroetilena (PTFE)

\section{INTRODUCTION}

Polytetrafluorethylene (PTFE) has been widely known as one of fluorocarbon polymers that has strong bonds exist between fluorine and carbon atoms. This specific molecular structure gives PTFE good combination of chemical, physical, and electrical properties (Qian et al. 2016). Due to low PTFE surface energy, its surface properties such as hydrophilicity, adhesivity and printability tend not to meet the requirements for industrial applications (Sun et al. 2018). In order to tackle these drawbacks, various enhancements have been made to modify its surface properties such as crosslinking (Wang et al. 2019), laser ablation (Qin et al. 2019) and (Yin et al. 2018), atomic layer deposition (Krumpolec et al. 2016), co-deposition (Li et al. 2019) and (Song et al. 2017), plasma treatment (Cheng et al. 2019) and radiation induced grafting polymerization (López et al. 2019; Park et al. 2016a).

RIGP is an advantageous method of modifying base polymers because grafting may result in the superimposition of properties related to the backbone and grafted chain. 
However, PTFE films will undergo degradation by exposure to radiation hence the tolerance dose has been reported to be between 5 and $60 \mathrm{kGy}$, depending on the irradiation condition (Martínez et al. 2018). By using the right choice of monomers with exclusive functional group, new molecular functionalities can be impregnated onto base polymer by RIGP (Taimur et al. 2018). Figure 1 shows the mechanism of RIGP of polymer by pre-irradiation method. Briefly, the trunk polymer PTFE was irradiated by electron beam in vacuum or inert gas to produce stable free radicals. These stable free radicals were then reacted with monomer within the required time.

There are numerous variety of graft copolymers that can be formed by RIGP. The monomer used for grafting will determine the type of copolymer formed. The classification is either neutral or ionic copolymer. Examples of neutral monomers are perfluoroacrylate and acrylamide (Magaña et al. 2015). Ionic copolymer may be divided into anionic, cationic and bipolar. Example for anionic monomers are polystyrene-divinylbenzene (PS/DVB) (Kaltz et al. 2018) and glycidyl methacrylate (GMA) followed by reaction with triethyl amine (Mahmoud et al. 2016). Meanwhile acrylic acid (Jiang et al. 2019), poly(sodium 4-styrenesulfonate) (PSS) (Chen et al. 2018) and GMA followed by reaction with sodium sulphite (Shin et al. 2017) resulted in cationic copolymer. Example of bipolar monomer is GMA then followed by reaction with amino acid (Selin \& Emik 2018).

There are two types of monomers; functionalized monomers and non-functionalized monomers. Functionalized monomers are the monomers that provide the desired properties when copolymerized on polymer substrate. As an example, perfluoroethyl alkyl acrylate produces highly fluorinated graft side chains which result in a very hydrophobic copolymer (Gengec et al. 2016) while acrylamide results in hydrophilic copolymer (Sh et al. 2018). Meanwhile, non-functionalized monomers are another option to subject the copolymer to post grafting reaction where side chain is chemically converted to give desired functionality. GMA is one of the examples that produces epoxy functional side chain groups (Kim \& Lee 2017). The epoxy group can then be reacted with other materials including imidazole (Selambakkannu et al. 2018), ammonium 12-molybdophosphate (AMP) (Seko et al. 2018) and amines (Gao et al. 2017).

Functionalized monomers that offer carboxylic group to the trunk polymer will modify the hydrophilic properties of the graft PTFE copolymer. The electronegative carboxyl and hydroxyl group anchored on the film surface will lead copolymer to become potential metal ion adsorbent (Wang et al. 2018). In this study, acrylic acid (AAC) was chosen as the grafting monomer to introduce carboxylic acid groups onto the surface of PTFE film via radiation grafting. The effect of radiation dose and time of grafting on $\mathrm{D}_{\mathrm{g}}$ and swelling behaviour were investigated through various characterization techniques including FTIR, SEM, AFM, XRD and optical water contact angle measurement. Moreover, the efficacy of the grafted sample was discovered for the removal of metal ions from aqueous media.

\section{Materials AND Methods}

\section{MATERIALS}

PTFE polymer in the form of aqueous dispersion (FR301B) was purchased from 3F New Materials Co., Ltd., Shanghai, China. Ethylene glycol (6207) additive was supplied by

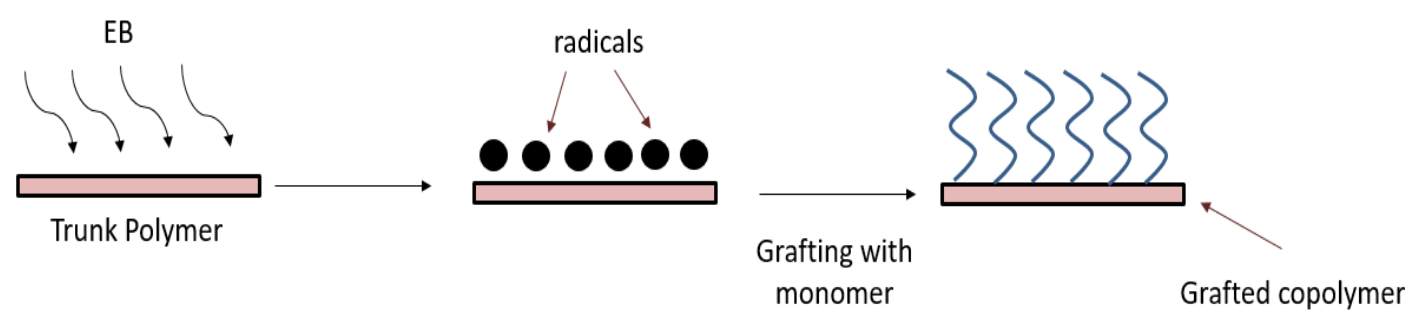

FIGURE 1. Mechanism of radiation induced grafting polymerization of polymer by pre-irradiation method

(a)

$$
+\mathrm{CF}_{2}-\mathrm{CF}_{2}+_{n} \stackrel{\text { EB radiation }}{\longrightarrow}+\mathrm{CF}_{2}-\dot{\mathrm{C}} \mathrm{F}{ }_{\mathrm{n}}
$$

(b)

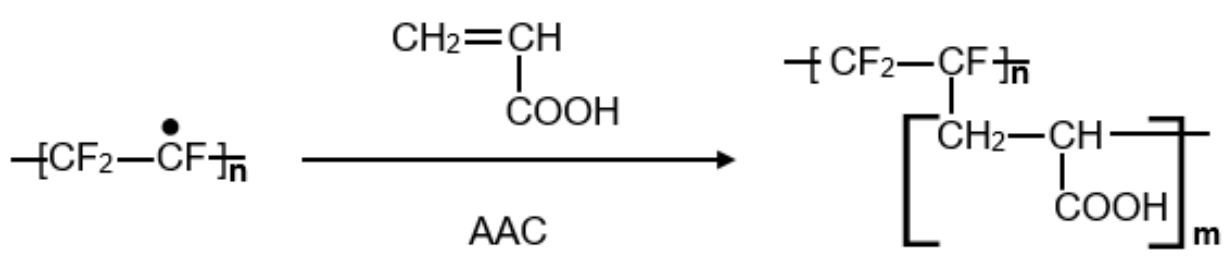

FIGURE 2. Reaction schemes for (a) preirradiation step (represent radical) and (b) the preparation of PTFE-g-AAC 
Merck. Sodium benzoate (144.11) salts was provided by Riedel-de-Haen. AAC and methanol were purchased from Merck and used without purification. Cations standard solutions 1000 ppm (BDH Chemicals) were obtained from Bahagian Alam Sekitar (BAS) Agensi Nuklear Malaysia.

\section{PREPARATION OF PTFE FLAT SHEET FILM}

PTFE flat sheet film was prepared by casting and sintering technique as described in the previous study (Ghani et al. 2017). Briefly, sodium benzoate was dissolved in the mixture of PTFE and ethylene glycol solution and then casted on glasGhanis plate. The film was then sintered at $385^{\circ} \mathrm{C}$ in an oven and was leached by immersing in hot water. The resulted PTFE flat sheet film was used as substrate for irradiation and grafting process.

\section{PREPARATION OF RADIATION INDUCED GRAFT POLYMERIZATION OF PTFE FLAT SHEET FILM}

Irradiation of PTFE Flat Sheet Film PTFE flat sheet film was cut into $2.5 \mathrm{~cm} \times 2.5 \mathrm{~cm}$ sized pieces. The film was then washed with acetone and dried in a vacuum oven ( 1 torr) at $50^{\circ} \mathrm{C}$ for $1 \mathrm{~h}$. PTFE film was purged with nitrogen gas in polyethylene bag and sealed. The film was placed on dry ice and irradiated with an electron beam (EB). Parameters of the EB and irradiation conditions are given in Table 1. After irradiation, the film was quickly stored at $-80^{\circ} \mathrm{C}$.

TABLE 1. Electron beam parameters and irradiation conditions of PTFE flat sheet film

\begin{tabular}{cc}
\hline Irradiation parameter & Conditions \\
\hline Energy & $2 \mathrm{MeV}$ \\
Current & $3 \mathrm{~mA}$ \\
Dose & $10-50(10,20,30,40,50) \mathrm{kGy}$ \\
Dose per pass & $10 \mathrm{kGy}$ \\
Atmosphere & Nitrogen \\
\hline
\end{tabular}

Copolymerization of PTFE with AAC AAC monomer solution was prepared by adding $30 \mathrm{wt}$ \% of AAC to distilled water. The monomer solution was stirred at room temperature with magnetic stirrer for $10 \mathrm{~min}$ followed by stirring with high speed homogenizer for $15 \mathrm{~min}$ and deaerated with nitrogen gas. The monomer was sucked into an evacuated glass ampoule in which the irradiated PTFE film was transferred. The glass ampoule was placed in water bath to initiate graft polymerization of AAC onto PTFE film. The grafting reaction was then allowed to react from 1 to $3 \mathrm{~h}$ at $40^{\circ} \mathrm{C}$. After the reaction, the grafted film was recovered from the ampoules and washed repeatedly with hot water and methanol to remove homopolymer. The grafted film was dried overnight at $40^{\circ} \mathrm{C} . \mathrm{D}_{\mathrm{g}}$ was calculated by gravimetric method using (1):

$$
\mathrm{D}_{\mathrm{g}}(\%)=\left(\mathrm{W}_{\mathrm{g}}-\mathrm{W}_{\mathrm{o}}\right) / \mathrm{W}_{\mathrm{o}} \times 100
$$

where $\mathrm{W}_{\mathrm{o}}$ and $\mathrm{W}_{\mathrm{g}}$ represent the weights of initial and grafted film, respectively. The PTFE grafting reaction is schematized in Figure 2.

\section{POTENTIAL ADSORPTION STUDY OF PTFE-G-AAC FILM}

Metal ions adsorption of the grafted PTFE films were performed by batch adsorption to study the potential use as an adsorbent of heavy metal. Several cations which commonly exists in waste water were selected namely cadmium $(\mathrm{Cd})$, copper $(\mathrm{Cu})$, iron $(\mathrm{Fe})$, nickel $(\mathrm{Ni})$, lead $(\mathrm{Pb})$, zinc $(\mathrm{Zn})$ and zirconium $(\mathrm{Zr})$. Fifty $\mathrm{mg}$ of adsorbent weight were soaked in $20 \mathrm{~mL}$ cation solution with $10 \mathrm{ppm}$ of metal solutions for $4 \mathrm{~h}$ at $\mathrm{pH} 6$. The experiment were carried out at room temperature. Cations concentration were measured by Inductively Coupled Plasma Mass Spectometry (ICP-MS) Perkin-Elmer NexION 350× (United States). The removal efficiency was calculated by the following equation:

$$
\text { Removal efficiency }(\%)=\left(C_{o}-C_{e}\right) / C_{o} \times 100
$$

where $C_{o}$ and $C_{e}$ are initial and final cations concentrations, respectively.

\section{CHARACTERIZATION OF PTFE-G-AAC FILM}

The grafting monomers was confirmed by ATR-FTIR Tensor II, Bruker (United State). The spectra were measured in a wavenumber range $4000-500 \mathrm{~cm}^{-1}$. Crystalline structures of the grafted PTFE (PTFE-g-AAC) film was analysed by XRD Panalytical X'Pert Pro MRD (Netherlands) equipped with a $\mathrm{Cu} \mathrm{K} \alpha$ radiation source $(40 \mathrm{kV}, 30 \mathrm{~mA})$. The sample was scanned in the range of diffraction angle $2 \theta$ from $5^{\circ}$ to $90^{\circ}$. Crystallinity index (CrI) was calculated using the intensity values corresponding to the diffraction of the crystalline structure and the amorphous fraction following Segal method (Singha et al. 2014).

$$
\operatorname{CrI}(\%)=\left(\mathrm{I}_{100}-\mathrm{I}_{\mathrm{am}}\right) / \mathrm{I}_{100} \times 100
$$

where $I_{100}$ is the intensity of the crystalline peak at the maximum; and $\mathrm{I}_{\mathrm{am}}$ is the intensity at the minimum. The changes in terms of hydrophilicity of PTFE-g-AAC film were assessed based on the measurement of the static contact angle of water using Attension Optical Tensiometer Contact Angle Meter (Theta, Biolin Scientific., Stockholm, Sweden) at $25^{\circ} \mathrm{C}$ and at $40-50 \%$ relative humidity. The average of five measured values for each sample were taken as its optical contact angle. EDS was determined gravimetrically. The PTFE-g-AAC film was immersed in distilled water for $24 \mathrm{~h}$ at room temperature. The sample was removed from the distilled water and filter paper was used to remove any surface water before the weight of sample was determined. The EDS was calculated using the following equation: 


$$
\operatorname{EDS}(\%)=\left(\mathrm{W}_{\mathrm{s}}-\mathrm{W}_{\mathrm{g}}\right) / \mathrm{W}_{\mathrm{g}} \times 100
$$

where $\mathrm{W}_{\mathrm{g}}$ and $\mathrm{W}_{\mathrm{s}}$ represent the weights of the initial and swollen grafted PTFE flat sheet films. The surface topography of the PTFE and PTFE-g-AAC films were studied using a SEM Phenom, G2 Pro (Eindhoven, The Netherlands). Surface roughness of the PTFE films were analysed at room temperature by AFM JPK NanoWizard II (Germany) in $5 \mu \mathrm{m} \times 5 \mu \mathrm{m}$ scanning field.

\section{RESULTS AND DisCUSSION}

EFFECT OF IRRADIATION DOSE AND GRAFTING TIME ON D ${ }_{G}$

The radiation induced grafting of AAC onto PTFE film was carried out at two different conditions: irradiation dose from 10 to $50 \mathrm{kGy}$ on $\mathrm{D}_{\mathrm{g}}$; and grafting time from 1 to $3 \mathrm{~h}$. Figure 3 shows the $\mathrm{D}_{\mathrm{g}}$ obtained with different irradiation dose and grafting time. It can be seen that the $\mathrm{D}_{\mathrm{g}}$ increases gradually with increasing irradiation dose and time of grafting. At $2 \mathrm{~h}$ of grafting, $\mathrm{D}_{\mathrm{g}}$ increased from $36 \%$ to $98 \%$ when the irradiation dose increased from $10 \mathrm{kGy}$ to 50 $\mathrm{kGy}$. This can be explained by the fact that with increasing irradiation dose, the production of radicals on the PTFE film increased. Thus, more radicals were available to take part in the grafting polymerization reaction hence the increase in $\mathrm{D}_{\mathrm{g}}$. This results is supported by Hegazy (2012) that grafted AAC onto non-woven polypropylene sheet. Meanwhile at $10 \mathrm{kGy}, \mathrm{D}_{\mathrm{g}}$ increased from $16 \%$ to $57 \%$ when the grafting time increased from 1 to $3 \mathrm{~h}$. As the time of grafting increased, the number of monomer molecules that diffused onto PTFE chains increased. Furthermore, the monomer also reacted with grafted AAC to form longer chains thus resulted in higher $\mathrm{D}_{\mathrm{g}}$. Similar trend was reported

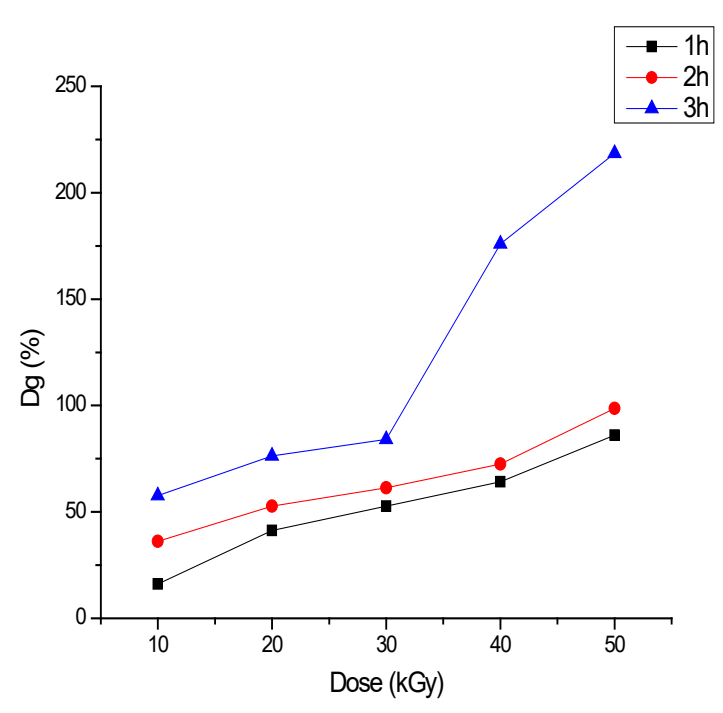

FIGURE 3. Effect of irradiation dose and grafting time on $\mathrm{Dg}$ for grafting of poly(methyl methacrylate) and poly(vinyl imidazole) onto PTFE films (López et al. 2019).

FTIR ANALYSIS OF PTFE-G-AAC FILM

Figure 4 indicates FTIR spectra of the PTFE and PTFE-gAAC films. FTIR spectra for PTFE film shows strong absorption bands at $1200 \mathrm{~cm}^{-1}$ and $1146 \mathrm{~cm}^{-1}$ due to stretching vibrations of $\mathrm{CF}_{2}$ in PTFE film. New bands were observed in the FTIR spectra for PTFE-g-AAC film. Most noticeably, peak at $1712 \mathrm{~cm}^{-1}$ which is assigned to carbonyl band $\mathrm{C}=\mathrm{O}$ of the carboxylic acid. Furthermore, the PTFEg-AAC film displays a very broad band at $3000-3750 \mathrm{~cm}^{-1}$ attributed to $\mathrm{O}-\mathrm{H}$ stretching vibration, while a $\mathrm{C}-\mathrm{H}$ stretching vibration observed at $2850-2970 \mathrm{~cm}^{-1}$ and the $\mathrm{C}-\mathrm{H}$ bending vibration at $1470 \mathrm{~cm}^{-1}$. These new bands observed after grafting confirmed the successful introduction of AAC onto PTFE flat sheet film. Similar findings was reported by Essawy et al. (2017).

\section{CRYSTALLINITY ANALYSIS OF PTFE-G-AAC FILM}

XRD analysis of PTFE and PTFE-g-AAC films were performed to clarify the changes in their crystallinity as presented in Figure 5. The PTFE film shows an intense peak centered at $17.9^{\circ}$ corresponding to the diffraction from (1 $00)$ planes with a spacing of $4.9 \AA$ in semicrystalline PTFE that consists of lamellar crystal. It can be seen that the intensity of the PTFE-g-AAC diffractogram, representing the crystallinity decreases after grafting polymerization with AAC. This decrement is also proven by the decrease of CrI from $99.8 \%$ for PTFE to $98.6 \%$ for PTFE-g-AAC film. This is due to the dilution of the crystalline region of PTFE by incorporation of grafting polymerization hydrophilic AAC chains. This finding is supported by Moawia et al. (2016). The interaction of the hydrogen bond

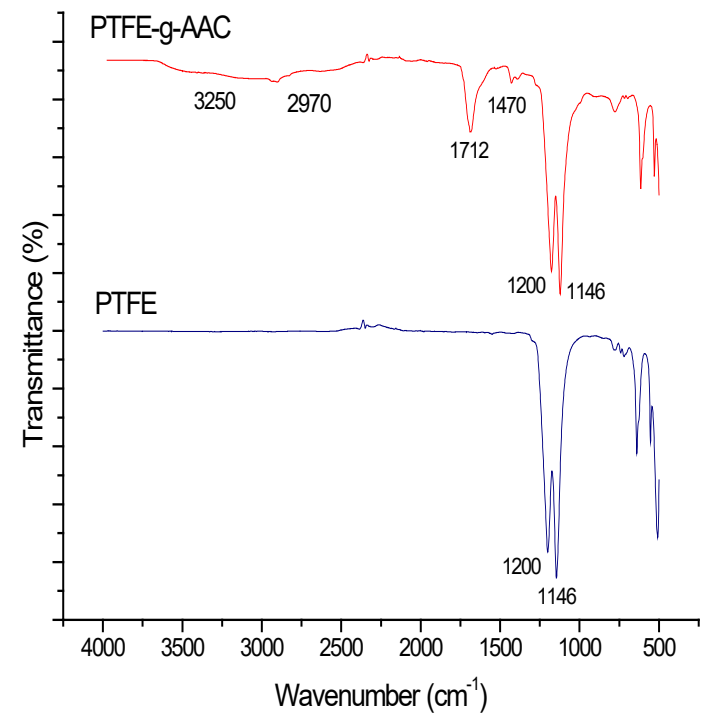

FIGURE 4. FTIR-ATR spectra of PTFE and PTFE-g-AAC flat sheet film 


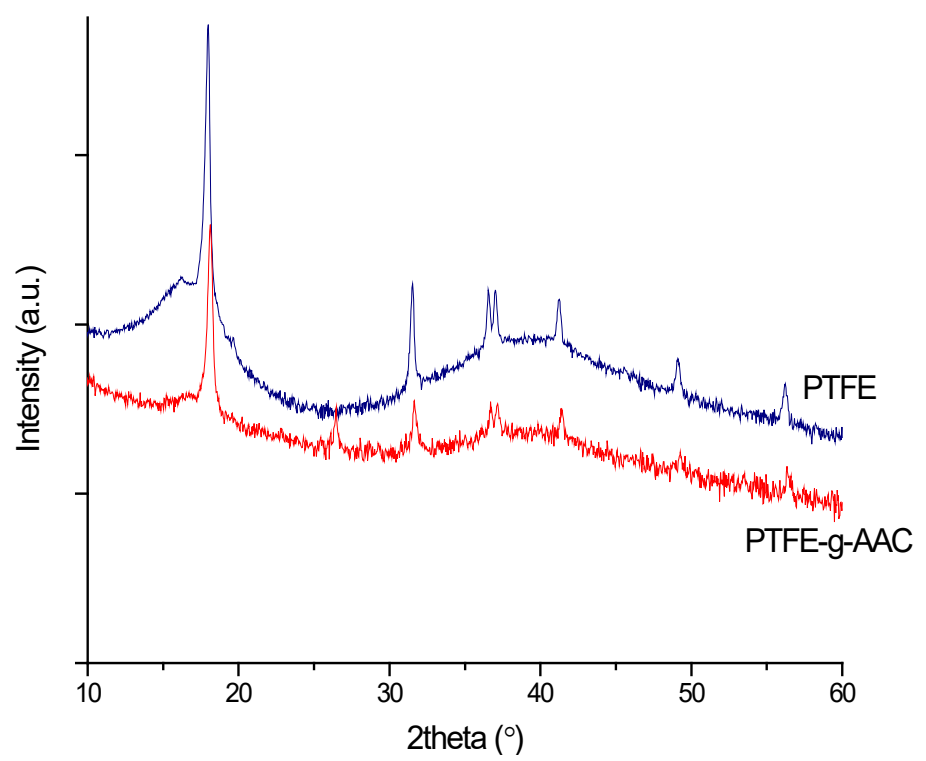

FIGURE 5. XRD diffractogram of the PTFE and PTFE-g-AAC flat sheet film

that exist in $\mathrm{COOH}$ groups of AAC thus enhanced the permeability of water throughout the amorphous layer of the film as supported by Wang et al. (2010). Furthermore, the diffraction peaks display a noticeable right-shift after grafting polymerization with AAC. This indicates that the unit cell parameters or interlayer space of PTFE was slightly expanded due to AAC grafting polymerization as supported by Xu et al. (2012).

\section{HYDROPHILICITY ANALYSIS OF PTFE-G-AAC FILM}

The hydrophilicity of PTFE and PTFE-g-AAC film are presented in Figure 6. The optical water contact angle of PTFE film is $147^{\circ}$, which is greater than $90^{\circ}$, indicating

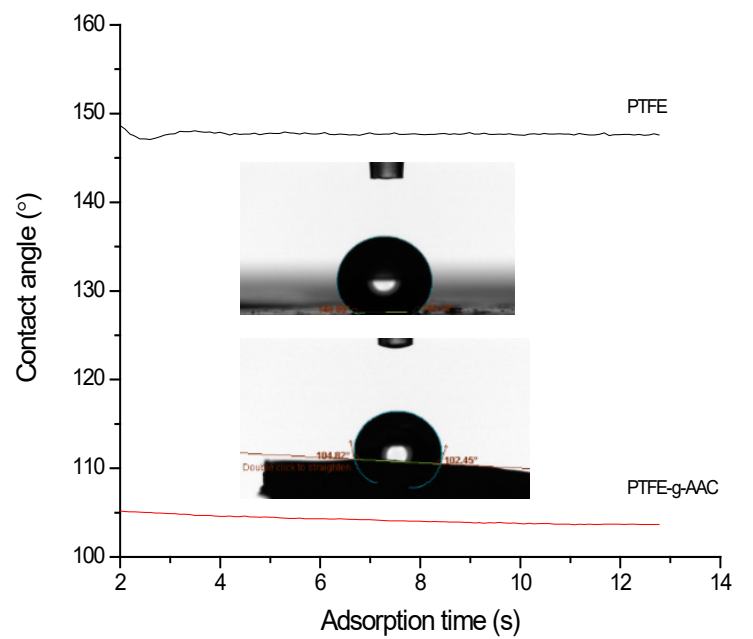

FIGURE 6. Curve of optical contact angle of PTFE and PTFE-gAAC subjected to adsorption time. The inserts in the middle are the photographs of the water droplet on the films
PTFE film is super-hydrophobic. This is due to the fluorine atoms in the external layer of the chemical structure $\left[-\left(\mathrm{CF}_{2}-\right.\right.$ $\mathrm{CF}_{2}$ )-] that possessed high electronegativity and have strong interaction with carbon. After grafting polymerization with AAC, the contact angle was reduced to $104^{\circ}$. This decrement was due to the existence of hydrophilic group such as carboxyl and hydroxyl group in PTFE-g-AAC film. This findings was supported by Yang et al. (2013) that modified PVDF films by radiation induced grafting.

\section{SWELLING BEHAVIOUR OF PTFE-G-AAC FILM}

Figure 7 indicates the increase in the EDS of PTFE-g-AAC film with increasing $\mathrm{D}_{\mathrm{g}}$. This is due to the increase of the

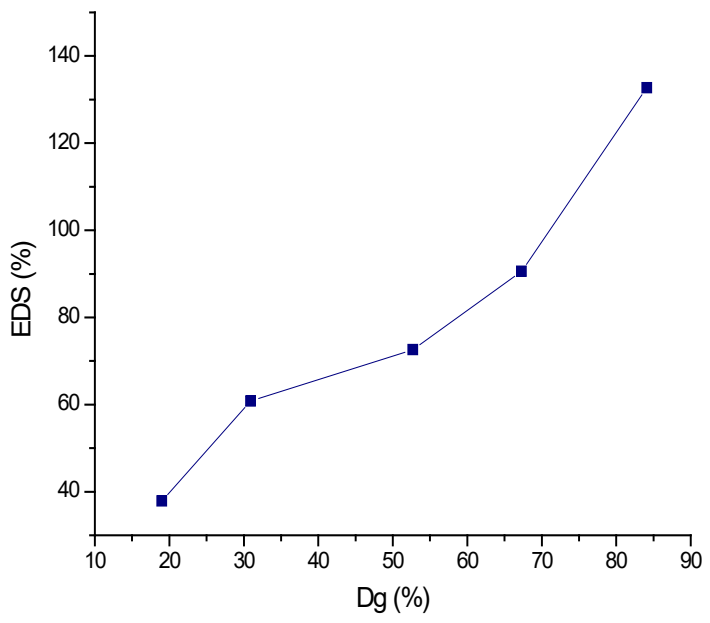

FIGURE 7. Equilibrium degree swelling as a function of degree of grafting Dg 

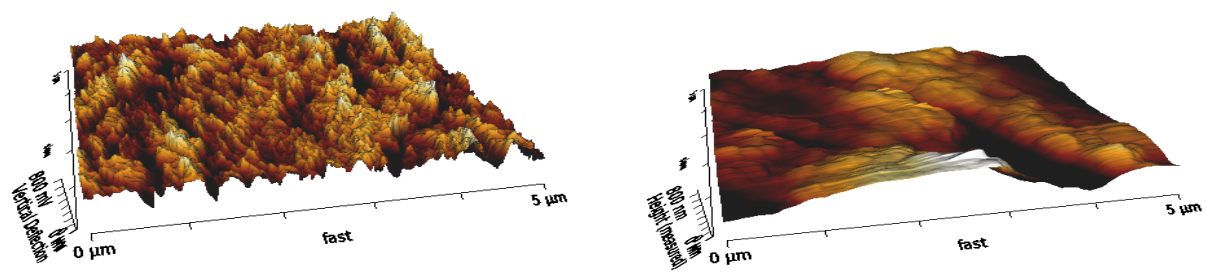

FIGURE 8. AFM images and surface roughness parameter of (a) PTFE and (b) PTFE-g-AAC flat sheet films [Ra: average roughness, Rt: peak to valley roughness, Rq: RMS roughness]

hydrophilic groups introduced into the grafted film with the increase of $\mathrm{D}_{\mathrm{g}}$. Moreover, the crystalline-amorphous changes in the film were another important factor influencing the water uptake. Once the crystallinity of the grafted film decreased, the water molecules could easily penetrate the non-crystalline region. As a result, the water uptake increased with an increasing grafting level and decreasing crystallinity. These results suggested that the degree of swelling depends mainly on the degree of grafting, amount of the hydrophilic groups in the PTFE-gAAC film. Similar trend was reported by Abdel et al. (2014).

SURFACE ROUGHNESS ANALYSIS OF PTFE-G-AAC FILM

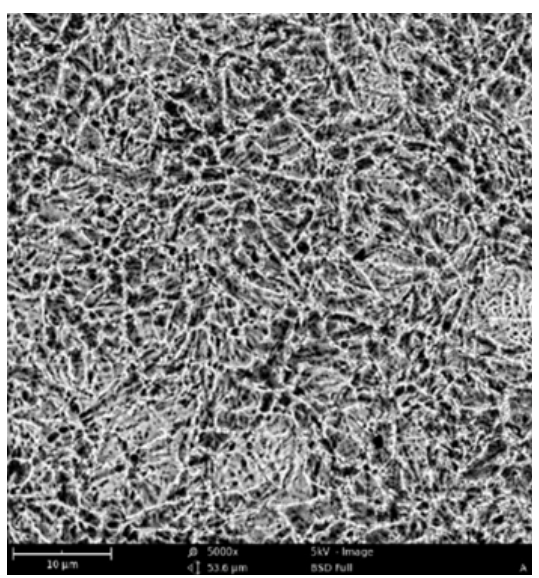

5 (a)

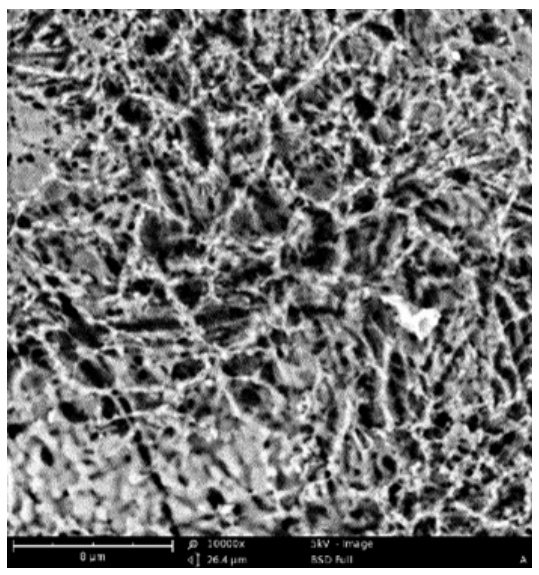

(c)
Figure 8 presents the AFM images and surface roughness parameter for the PTFE and PTFE-g-AAC films. It showed that the average roughness $\left(\mathrm{R}_{\mathrm{a}}\right)$ decreased from $102.2 \mathrm{~nm}$ to $88.17 \mathrm{~nm}$. The root mean square roughness $\left(\mathrm{R}_{\mathrm{q}}\right)$ showed similar trends which was slightly down from $125.5 \mathrm{~nm}$ to $111.7 \mathrm{~nm}$. These results are supported by Wu et al. (2019) that stated hydrophilic side chains could decrease the roughness of the surface. Furthermore, these changes of roughness parameters agree well with changes of hydrophilicity of the films, proposing that hydrophilicity may play a vital role in the surface roughness of the films. This findings is supported by Li et al. (2018) that enhancing water permeability of polyvinylidene fluoride membranes with carboxylated nanodiamonds. Interestingly, the peak

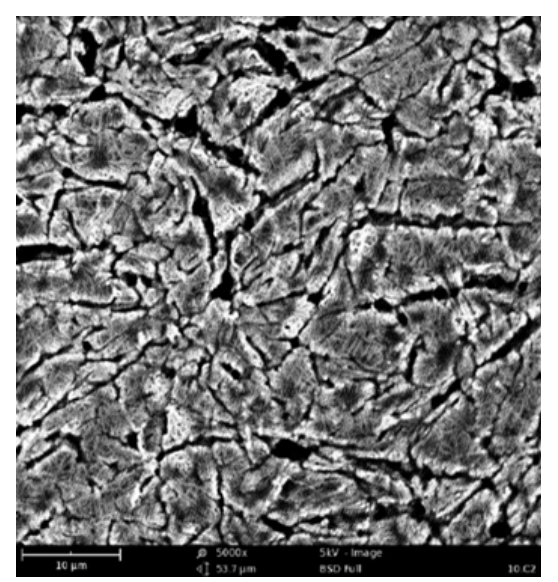

(b)

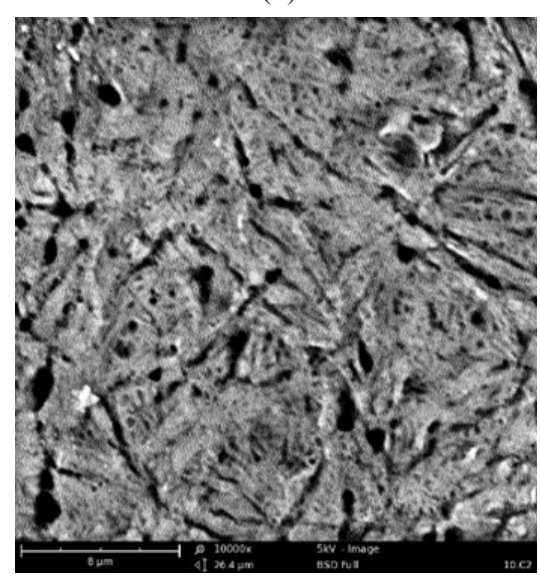

(d)

FIGURE 9. SEM images of the surface of (a) PTFE (b) PTFE-g-AAC at 5000 magnification; (c) PTFE (d) PTFE-g-AAC at 10000 magnification 
to valley roughness $\left(R_{t}\right)$ increased from $738.8 \mathrm{~nm}$ to 862.6 $\mathrm{nm}$ after PTFE film grafted with acrylic acid.

\section{MORPHOLOGY OF PTFE-G-AAC FILM}

The surface morphology of the PTFE and PTFE-g-AAC were examined by SEM as presented in Figure 9. The PTFE film was observed to contain fibrils interconnecting nodal region in the matrix (Figure 9(a) and 9(c)). The fibrils connecting the islands were randomly oriented in the film. This findings was supported by Hidzir et al. (2015) that grafted acrylic acid-co-itaconic acid onto ePTFE. Figure 9(b) and 9(d) shows less fibrillar regions meanwhile the islands region are clearly discernible correspond to grafting polymerization of AAC compared to Figure 9(a) and 9(c). This findings was consistent with Mohd et al. (2012) that grafting AAC onto expanded PTFE films.

\section{ADSORPTION POTENTIAL STUDY OF PTFE-G-AAC FILM}

A preliminary study was done to investigate the potential use of the PTFE-g-AAC film as heavy metal adsorbent in competitive media. Several metal ions which commonly exist in waste water were selected namely $\mathrm{Cd}, \mathrm{Fe}, \mathrm{Ni}, \mathrm{Pb}$, $\mathrm{Zn}$ and Zr. Figure 10 shows the removal efficiency of the grafted film towards metal ions. Obviously, the PTFE-gAAC films show highest removal efficiency for $\mathrm{Fe}(75.8 \%)$ followed by $\mathrm{Pb}(53.1 \%)$ and $\mathrm{Cu}(33.9 \%)$. While only 20 $25 \%$ for $\mathrm{Cd}$ and $\mathrm{Zr}$, and below $10 \%$ for $\mathrm{Ni}$ and $\mathrm{Zn}$ ions can be removed by PTFE-g-AAC films. Therefore, the removal efficiency observed can be ordered in the following way: $\mathrm{Fe}>\mathrm{Pb}>\mathrm{Cu}>\mathrm{Zr}>\mathrm{Cd}>\mathrm{Zn}>\mathrm{Ni}$.

There are some factors that could contribute for this selectivity of adsorption such as the size of the hydrated ion, hydrated-free energy, activity and electronegativity of

TABLE 2. Ionic properties, free energy of hydration and electronegativity of the metal ions

\begin{tabular}{|c|c|c|c|c|}
\hline Metal ions & Ionic radius $(\AA)^{\mathrm{a}}$ & Hydrated radius $(\AA)^{\mathrm{b}}$ & Hydration-free energy $(\mathrm{kJ} / \mathrm{mol})^{\mathrm{a}}$ & Electronegativity $^{\mathrm{c}}$ \\
\hline $\mathrm{Cd}$ & 0.95 & 4.26 & -1755 & 1.83 \\
\hline $\mathrm{Cu}$ & 0.73 & 4.19 & -2010 & 1.87 \\
\hline $\mathrm{Fe}$ & 0.78 & 4.28 & -1840 & 1.90 \\
\hline $\mathrm{Ni}$ & 0.69 & 4.04 & -1980 & 1.33 \\
\hline $\mathrm{Pb}$ & 1.18 & 4.01 & -1425 & 1.69 \\
\hline $\mathrm{Zn}$ & 0.74 & 4.30 & -1955 & 1.65 \\
\hline $\mathrm{Zr}$ & 0.72 & - & -6790 & 1.91 \\
\hline
\end{tabular}

${ }^{a}$ The ionic radius and the hydration-free energy were obtained from Marcus (1994) b ${ }^{\mathrm{b}}$ The hydrated radius was obtained from Nightingale (1959) ${ }^{\mathrm{c}}$ The electronegativity was obtained from Pauling (1960)

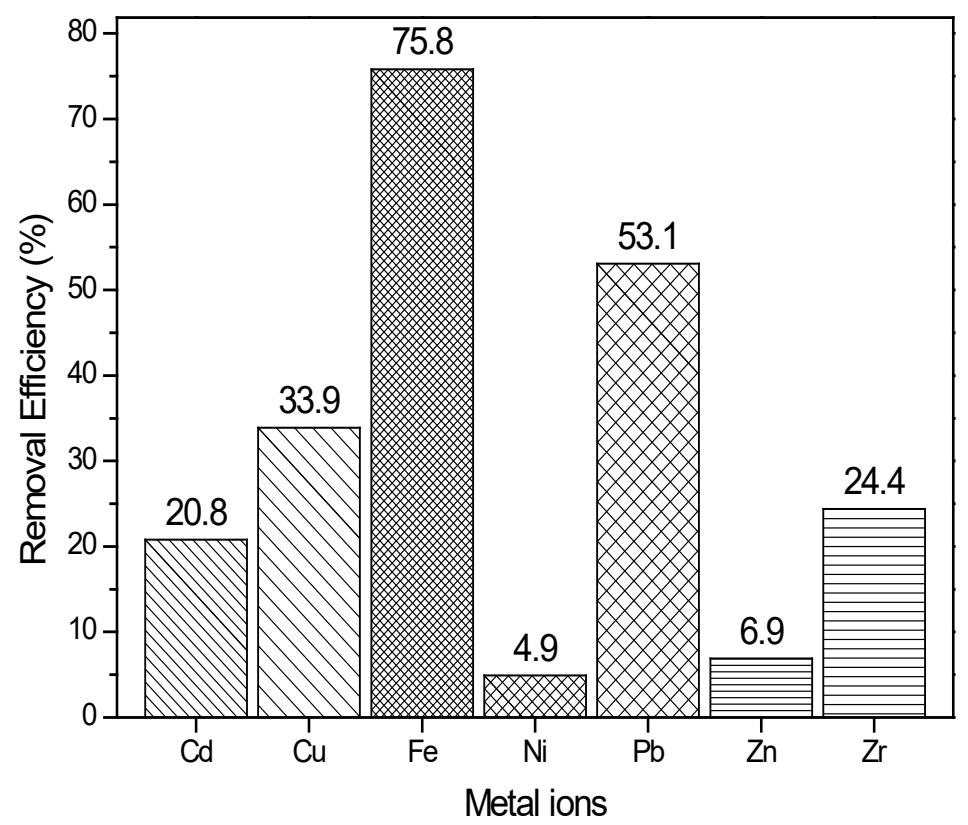

FIGURE 10. Removal efficiency of PTFE-g-AAC film towards metal ions 
the metal ions (Jain et al. 2016; Liu et al. 2018). The hydrated radius, free energy of hydration and electronegativity data are shown in Table 2 . The order of the hydrated radius is $\mathrm{Zn}>\mathrm{Fe}>\mathrm{Cd}>\mathrm{Cu}>\mathrm{Ni}>\mathrm{Pb}$ and the free energy of hydration is $\mathrm{Zr}>\mathrm{Cu}>\mathrm{Ni}>\mathrm{Zn}>\mathrm{Fe}>$ $\mathrm{Cd}>\mathrm{Pb}$. Meanwhile, the order of heavy metal reactivity is $\mathrm{Zn}>\mathrm{Fe}>\mathrm{Cd}>\mathrm{Ni}>\mathrm{Pb}>\mathrm{Cu}$ and electronegativity is $\mathrm{Ni}>\mathrm{Cu}>\mathrm{Pb}>\mathrm{Fe}>\mathrm{Cd}>\mathrm{Zn}>\mathrm{Zr}$. The affinity of the metal ions is dependent on the electronegativity and the size of the hydrated ion. The smaller the radius and higher electronegativity lead to the higher affinity (Park et al. 2016b). Meanwhile, higher hydration of free energy may cause the metal ion to remain in the aqueous hence reduced the possibility of being adsorbed. According to the order of the hydrated radius, electronegativity and free energy hydrated, $\mathrm{Pb}$ should be the most favorable ion to be adsorbed. Nevertheless, it is noted that the removal efficiency of $\mathrm{Fe}$ is higher than $\mathrm{Pb}$ that may be due to reactivity of the $\mathrm{Fe}$ ion is higher than $\mathrm{Pb}$. The adsorption of metal ions is probably due to hydroxyl and carbonyl groups present in the PTFE-g-AAC film which endowed it with strong affinity towards metal ions and form complexes, consistent with Xu et al. (2019).

\section{Conclusion}

This study has demonstrated the successful radiation induced grafting polymerization of AAC onto PTFE flat sheet film. The $\mathrm{D}_{\mathrm{g}}$ was found to be dependent on the irradiation dose and the time of grafting. The higher the irradiation dose and longer reaction time, the higher the $\mathrm{D}_{\mathrm{g}}$. The surface of PTFE-g-AAC films showed significant changes from hydrophobic surface to hydrophilic surface that was demonstrated by optical water contact angle and swelling behaviour. XRD, ATR-FTIR, SEM and AFM were able to demonstrate the overall physicochemical changes including crystallinity, functional groups, morphology and surface roughness the film. In addition, PTFE-g-AAC film has the potential to be an adsorbent for metal ion removal from aqueous solutions. It was shown that at least $75 \%$ of Fe ion can be removed in competitive media.

\section{ACKNOWLEDGEMENTS}

The authors gratefully acknowledge the financial support from the Ministry of Higher Education, Malaysia and Universiti Teknologi Malaysia (UTM) under MyBrain Fellowship and Fundamental Research Grant Scheme, FRGS (R.J130000.7826.4F752) and (Q. J130000.2546.18H90). The authors would also like to acknowledge technical and management support from Radiation Processing Technology Division, Malaysian Nuclear Agency and Research Management Centre (RMC), Universiti Teknologi Malaysia.

\section{REFERENCES}

Abdel Ghaffar, A.M., El-Arnaouty, M.B., Aboulfotouh, M.E., Taher, N.H. \& Ahmed A.T. 2014. Radiation graft copolymerization of butyl methacrylate and acrylamide onto low density polyethylene and polypropylene films, and its application in wastewater treatment. Radiation Effects and Defects in Solids 169(9): 741-753.

Chen, M., Karen, S.P., Stephen, J.R. \& Edward, P. 2018. Competitive association of cations with poly (sodium 4-styrenesulfonate) (PSS) and heavy metal removal from water by PSS-assisted ultrafiltration. Chemical Engineering Journal 344: 155-164.

Cheng, B., Yuuki, I. \& Kazuhiko, I. 2019. Surface functionalization of polytetrafluoroethylene substrate with hybrid processes comprising plasma treatment and chemical reactions. Colloids and Surfaces B: Biointerfaces 173: 77-84.

Essawy, H.A., Magdy, F.M., Nabila, S.A. \& Hanan, S.I. 2017. The promise of a specially-designed graft copolymer of acrylic acid onto cellulose as selective sorbent for heavy metal ions. International Journal of Biological Macromolecules 103: 261-267.

Gao, Q., Jiangtao, H., Rong, L., Zhe, X., Lijuan, P. \& Mingxing, Z. 2019. Radiation-induced graft polymerization for the preparation of a highly efficient UHMWPE fibrous adsorbent for $\mathrm{Cr}$ (VI) removal. Radiation Physics and Chemistry 130: 92-102.

Gengec, N.A., Ugur, C. \& Yildirim, H.E. 2016. Superhydrophobic perfluoropolymer/polystyrene blend films induced by nonsolvent. Applied Surface Science 383: 33-41.

Ghani, F.A., Hamzah, K., Salleh, W.W.N. \& Mohamed, N.H. 2017. Preparation and characterization of PTFE flat sheet membrane: Effect of sodium benzoate content. Malaysian Journal of Fundamental and Applied Sciences 13(4): 598601.

Hegazy, D.E. 2012. Selectivity of acrylic acid radiation grafted non-woven polypropylene sheets towards some heavy metals ions. Open Journal of Polymer Chemistry 2: 6-13.

Hidzir, N.M., Qianhui, L., David, J.T.H., Firas, R. \& Lisbeth, G. 2015. Grafting of acrylic acid-co-itaconic acid onto ePTFE and characterization of water uptake by the graft copolymers. Journal of Applied Polymer Science 132(7): 41482.

Jain, M., Garg, V.K., Kadirvelu, K. \& Sillanpää, M. 2016. Adsorption of heavy metals from multi-metal aqueous solution by sunflower plant biomass-based carbons. International Journal of Environmental Science and Technology 13(2): 493-500.

Jiang, C., Xiaohong, W., Ganghu, W., Chen, H., Xin, L. \& Tihai, L. 2019. Adsorption performance of a polysaccharide composite hydrogel based on crosslinked glucan/chitosan for heavy metal ions. Composites Part B: Engineering 169: 45-54.

Kaltz, A., Lea, B., Jonathan, S.T. \& Andreas, S. 2018. Investigations on the selectivity of grafted high performance anion exchangers and the underlying graft mechanism. Analytica Chimica Acta 999: 176-183.

Kim, H.H. \& Lee, G.T. 2017. Removal of mercury ions in a simulated wastewater using functionalized poly(glycidyl 
methacrylate). Journal of Industrial and Engineering Chemistry 47: 446-450.

Krumpolec, R., David, C.C., Tomáš, H. \& Mirko, Č. 2016. Surface chemistry and initial growth of $\mathrm{Al}_{2} \mathrm{O}_{3}$ on plasma modified PTFE studied by ALD. Surfaces and Interfaces 6: 223-228

Li, C., Zehua, H., Feng, W., Hailin, Z., Yuhai, G. \& Meiyu, C. 2019. Laccase-catalyzed homo-polymer of GAL and crosslinking with PEI to enhance hydrophilicity and antifouling property of PTFE flat membrane. Progress in Organic Coatings 132: 429-439.

Li, Y., Shaobin, H., Shaofeng, Z., Anthony, G.F., Yongqing, Z. \& Shuaifei, Z. 2018. Enhancing water permeability and fouling resistance of polyvinylidene fluoride membranes with carboxylated nanodiamonds. Journal of Membrane Science 556: 154-163.

Liu, L., Xiaoping, G., Shuqi, W., Lei, L., Yang, Z. \& Guanhong, L. 2018. Effects of wood vinegar on properties and mechanism of heavy metal competitive adsorption on secondary fermentation based composts. Ecotoxicology and Environmental Safety 150(35): 270-279.

López, S.F., Guadalupe, G.F.R., Beatríz, M., Angel, C., Carmen, A.L. \& Emilio, B. 2019. Radiation grafting of poly(methyl methacrylate) and poly(vinylimidazole) onto polytetrafluoroethylene films and silver immobilization for antimicrobial performance. Applied Surface Science 473: 951-959.

Magaña, H., Kenia, P., Jose, M.C.B., Carmen, A.L., Angel, C. \& Emilio, B. 2015. Radiation-grafting of acrylamide onto silicone rubber films for diclo-fenac delivery. Radiation Physics and Chemistry 107: 164-170.

Mahmoud, M.N., Ting, T.M., Ali, A., Alireza, L.M., Alinezhad, S.S. \& Hashim, K. 2016. Radiation grafted adsorbents for newly emerging environmental applications. Radiation Physics and Chemistry 118: 55-60.

Marcus, Y. 1994. A simple empirical model describing the thermodynamics of hydration of ions of widely varying charges, sizes, and shapes. Biophysical Chemistry 51: 111127.

Martínez, C.A., Juan, C.R., Evelyne, K., Alejandra, O., Lorena, G.U., Pierre, L.G.L. \& Guillermina, B. 2018. Primaryamine surface functionalization of polytetrafluoroethylene films by radiation grafting of aminated polyacryloyl chloride. Radiation Physics and Chemistry 149: 65-72.

Moawia, R.M., Mahmoud, M.N., Mohamed, N.H. \& Adnan, R. 2016. Modification of flax fibres by radiation induced emulsion graft copolymerization of glycidyl methacrylate. Radiation Physics and Chemistry 122: 35-42.

Mohd, N.H., David, J.T.H., Darren, M. \& Lisbeth, G. 2012. Radiation-induced grafting of acrylic acid onto expanded poly (tetrafluoroethylene) membranes. Polymer 53(26): 6063-6071.

Nightingale, E.R. 1959. Phenomenological theory of ion solvation. Effective radii of hydrated ions. Journal of Physical Chemistry 63(9): 1381-1387.

Park, B.H., Joon, Y.S. \& Junhwa, S. 2016a. Radiolytic preparation and characterization of hydrophilic poly(acrylonitrile-covinylsulfonate)-grafted porous poly (tetrafluoroethylene) substrates. Radiation Physics and Chemistry 118: 42-47.

Park, J.H., Yong, S.O., Seong, H.K., Ju, S.C., Jong, S.H., Ronald, D.D. \& Dong, C.S. 2016b. Competitive adsorption of heavy metals onto sesame straw biochar in aqueous solutions. Chemosphere 142: 77-83.
Pauling, L. 1960. The Nature of the Chemical Bond - An Introduction to Modern Structural Chemistry. 3rd ed. New York: Cornell University Press.

Qian, Y., Lina, C., Weili, Z., Zhenjiang, Y., Zhongzhi, Z., Zhenjia, Z. \& Zheng, J. 2016. Fabrication of $\mathrm{TiO}_{2}$-modified polytetrafluoroethylene ultrafiltration membranes via plasma-enhanced surface graft pre-treatment. Applied Surface Science 360: 749-757.

Qin, Z., Jun, A., Qifeng, D., Jianguo, L. \& Xiaoyan, Z. 2019. Superhydrophobic polytetrafluoroethylene surfaces with accurately and continuously tunable water adhesion fabricated by pico second laser direct ablation. Materials and Design 173: 107782

Seko, N., Hiroyuki, H., Noboru, K., Takuya, S., Seiichi, S. \& Yuji, U. 2018. Development of a water purifier for radioactive cesium removal from contaminated natural water by radiation-induced graft polymerization. Radiation Physics and Chemistry 143: 33-37.

Selambakkannu, S., Nor, A.F.O., Khomsaton, A.B., Shakirah, A.S. \& Zulhairun, A.K. 2018. A kinetic and mechanistic study of adsorptive removal of metal ions by imidazolefunctionalized polymer graft banana fiber. Radiation Physics and Chemistry 153: 58-69.

Selin, Ş. \& Serkan, E. 2018. Fast and highly efficient removal of 2,4-Dusing amino-functionalized poly (glycidyl methacrylate) adsorbent: Optimization, equilibrium, kinetic and thermodynamic studies. Journal of Molecular Liquids 260: 195-202.

Sh, A., Ahmed, G.I., Emad, M.E. \& Essam, M. 2018. Radiation grafting of acrylamide and maleic acid on chitosan and effective application for removal of Co(II) from aqueous solutions. Radiation Physics and Chemistry 144: 116124.

Shin, I.H., Seungkwan, H., Seung, J.L., Youn, S.S. \& Tak, H.K. 2017. Surface modification of PVDF membrane by radiation-induced graft polymerization for novel membrane bioreactor. Journal of Industrial and Engineering Chemistry 46: 103-110.

Singha, A.S., Ashish, G. \& Raj, K.R. 2014. Microwave assisted graft copolymerization of cellulosic fibers for removal of heavy metal ions from aqueous solution. International Journal of Polymer Analysis and Characterization 19: 318-331.

Song, H., Hongwei, Y., Lijing, Z., Lixin, X., Dichao, W. \& Hao, C. 2017. Durable hydrophilic surface modification for PTFE hollow fiber membranes. Reactive and Functional Polymers 114: 110-117.

Sun, S., Xiaolin, X., Hui, W., Yingfeng, W., Haiyan, P., Chengfu, Z., Yuesheng, L., Sheng, W. \& Xingping, Z. 2018. Grafting polytetrafluoroethylene micropowder via in situ electron beam irradiation-induced polymerization. Polymers 10: 503.

Taimur, S., Muhammad, I., Tariq, Y. \& Syed, W. 2018. Synthesis of modified sepiolite-g-polystyrene sulfonic acid nanohybrids by radiation induced graft polymerization. Radiation Physics and Chemistry 148: 19-24.

Wang, J., Chengcai, L., Feng, W., Bin, Y., Yunying, L., Huanzhong, Z. \& Hailin, Z. 2019. Hydrophilic modification of PTFE microfiltration flat membrane by crosslinking OCMCS-PEI to enhance anti-fouling property. Progress in Organic Coatings 135(1): 565-573.

Wang, S., Juan, L., Jinping, S. \& Tianzhi, Luo. 2010. Surface modification of porous poly(tetrafluoraethylene) film by 
a simple chemical oxidation treatment. Applied Surface Science 256(7): 2293-2298.

Wang, X., Pei, L., Fushu, L., Xuechun, W., Min, J. \& Laizhou, S. 2018. Adsorption of $\mathrm{Pb}$ (II) by a polyvinylidene fluoride membrane bearing chelating poly(amino phosphonic acid) and poly(amino carboxylic acid) groups. Adsorption Science \& Technology 36(9-10): 1571-1594.

Wu, C., Yudan, Z., Haitao, W., Jianhua, H. \& Xiaoliang, W. 2019. Formation of antifouling functional coating from deposition of a zwitterionic-co-nonionic polymer via 'grafting to' approach. Journal of Saudi Chemical Society 23(8): 1080-1089.

Xu, H., Hengfeng, Y., Jianguo, Y. \& Sen, L. 2019. Study on the competitive adsorption and correlational mechanism for heavy metal ions using the carboxylated magnetic iron oxide nanoparticles (MNPs-COOH) as efficient adsorbents. Applied Surface Science 473: 960-966.

Xu, Q., Yang, Y., Xiaozu, W., Zhaohui, W., Wanqin, J., Jun, H. \& Yong, W. 2012. Atomic layer deposition of alumina on porous polytetrafluoroethylene membranes for enhanced hydrophilicity and separation performances. Journal of Membrane Science 415-416: 435-443.

Yang, L., Jun-Fu, W., Kong-Yin, Z. \& Zi-An, L. 2013. Preparation of a hydrophilic PVDF membranes by electron beam induced grafting polymerization of acrylic acid. Advanced Materials Research 625: 273-276.

Yin, K., Haifeng, D., Zhi, L., Xinran, D. \& Ji, A.D. 2018 Multifunctional micro/nano-patterned PTFE nearsuperamphiphobic surfaces achieved by a femtosecond laser. Surface and Coatings Technology 345: 53-60.
Faezeah Abd Ghani \& Wan NorHaryati Wan Salleh Advanced Film Technology Research Centre (AMTEC)

Universiti Teknologi Malaysia

81310 Skudai, Johor Darul Takzim

Malaysia

Faezeah Abd Ghani, Khaidzir Hamzah* \& Wan NorHaryati Wan Salleh

UTM-MPRC Institute for Oil and Gas

Universiti Teknologi Malaysia

81310 Skudai, Johor Darul Takzim

Malaysia

Khaidzir Hamzah*

Faculty of Chemical and Energy Engineering (FCEE)

Universiti Teknologi Malaysia

81310 Skudai, Johor Darul Takzim

Malaysia

Nor Hasimah Mohamed

Radiation Processing Technology Division

Malaysian Nuclear Agency

43000 Kajang, Selangor Darul Ehsan

Malaysia

*Corresponding author; email: khaidzir@utm.my

Received: 25 February 2019

Accepted: 15 October 2019 